\title{
BioOne

\section{Habitat Associations of Stream Fishes in Protected Tallgrass Prairie Streams}

\author{
Author(s): E. C. Martin , J. E. Whitney and K. B. Gido K. J. Hase \\ Source: The American Midland Naturalist, 170(1):39-51. 2013. \\ Published By: University of Notre Dame \\ URL: http://www.bioone.org/doi/full/10.1674/0003-0031-170.1.39
}

BioOne (www.bioone.org) is a nonprofit, online aggregation of core research in the biological, ecological, and environmental sciences. BioOne provides a sustainable online platform for over 170 journals and books published by nonprofit societies, associations, museums, institutions, and presses.

Your use of this PDF, the BioOne Web site, and all posted and associated content indicates your acceptance of BioOne's Terms of Use, available at www.bioone.org/page/terms_of_use.

Usage of BioOne content is strictly limited to personal, educational, and non-commercial use. Commercial inquiries or rights and permissions requests should be directed to the individual publisher as copyright holder. 


\title{
Habitat Associations of Stream Fishes in Protected Tallgrass Prairie Streams
}

\author{
E. C. MARTIN, J. E. WHITNEY AND K. B. GIDO \\ Kansas State University, Division of Biology, 116 Ackert Hall, Manhattan 66506
}

AND

K. J. HASE

Tallgrass Prairie National Preserve, Cottonwood Falls, Kansas 66845

\begin{abstract}
AвSTRACT.-Describing fish habitat associations and their relevance to conservation remains a central challenge in stream fish ecology. Unfortunately, there are limited opportunities to investigate these associations in unaltered systems and identify critical habitats used by native fishes. Investigation of fish habitat associations in tallgrass prairie is especially vital, owing to their widespread destruction. Our study aim was to identify habitat factors associated with the distribution and density of fishes in two protected tallgrass prairie stream watersheds in eastern Kansas: Kings Creek on the Konza Prairie Biological Station (KPBS) and Fox Creek on the Tallgrass Prairie National Preserve (TPNP). We sampled fishes and measured eight habitat variables at three sites on KPBS (2006-2011) and four sites on TPNP (2008-2011). Multiple regression suggested that species richness was positively associated with pool area (partial $r=0.70)$ and discharge (partial $r=0.50)$ in Fox Creek $\left(\mathrm{df}=15, \mathrm{Adj} . \mathrm{R}^{2}=0.60, \mathrm{P}<\right.$ $0.001)$. In Kings Creek, species richness was only associated with pool area $\left(\mathrm{df}=17, \mathrm{R}^{2}=\right.$ $0.44, \mathrm{P}<0.001)$. Redundancy analyses showed common prairie fish species exhibit ontogenetic habitat associations, partitioning adults in deep and juveniles in shallow pools. Strong species area relationships in these minimally altered systems indicates large volume habitats have greater species richness, suggesting water diversions or extractions that reduce habitat are likely to cause declines in native biodiversity.
\end{abstract}

\section{INTRODUCTION}

Both abiotic and biotic factors act concurrently over spatial and temporal scales to govern the distribution and abundance of species (Resh, 1988; Moyle and Light, 1996; Grossman et al., 1998; Magoulick, 2000; Jackson et al., 2001; Comita et al., 2009). For example biotic interactions such as algivory, competition, and predation can determine community structure and species persistence in streams (Jackson and Buss, 1975; Power and Matthews, 1983; Power et al., 1985; Power, 1992; Layman and Winemiller, 2004). Among potential abiotic influences on stream fish communities, stream flow is thought to be a master variable (e.g., Poff et al., 1997; Marchetti and Moyle, 2001; Lobón-Cerviá and Rincón, 2004; Propst and Gido, 2004), but habitat structure (e.g., pool depth, large woody debris), which can be linked to flow, is also a strong determinant of community structure (e.g., Angermeier and Karr, 1984; Schlosser, 1987; Bond and Lake, 2003). The relative importance of biotic and abiotic factors likely varies across regions with different levels of intermittency, frequency, and predictability of discharge (Poff and Ward, 1989).

Prairie streams are characterized as having high flow variability and unpredictable disturbance events (Dodds et al., 2004), thus abiotic factors might be important in regulating fish abundances in these systems (Schlosser, 1985). Indeed, variable flows influence substrate composition, instream cover, and habitat size, which can influence fish community structure in Great Plains streams (Fischer and Paukert, 2008; Falke et al., 2010). For example variability in depth and flow parameters influence abundance, distribution, 
and persistence of Arkansas darter (Etheostoma cragini) in Colorado prairie streams (Labbe and Fausch, 2000). Similarly, Gelwick et al. (1997) found that variation in water depth affected habitat use in Oklahoma prairie streams. However, Statzner (1987) suggested biotic factors might govern prairie stream community structure in pools but not riffles because hydrologic variability is greater in riffles. These studies illustrate that the relative importance of biotic and abiotic factors in structuring fish communities, even within prairie streams, can vary with community composition and the environmental template.

In prairie streams, the disturbance regime as well as habitat structure varies with stream size (Schlosser, 1987). Drying is typically more intense in shallow headwaters, but flooding is more intense and habitats are deeper downstream because of increasing catchment area (Leopold and Miller, 1956). This spatial variation in disturbances might decouple fish habitat associations via effect of flooding or drying on habitat availability and species persistence. Moreover, differences in habitat (e.g., depth) might favor species with different life history traits; small bodied species with rapid turnover occupy headwaters and larger species with slower turnover are more likely to occur downstream (Schlosser, 1987). Because extirpations in headwaters are common, the influence of regional species pool on local communities is dependent on system connectivity (Labbe and Fausch, 2000; Fausch et al., 2002; Hitt and Angermeier, 2008).

North American tallgrass prairie is one of the most endangered ecosystems in the United States, with prairie losses estimated around 95\% (Samson and Knopf, 1994). Prairie streams are equally endangered because of fragmentation (Perkin and Gido, 2011), channelization and alterations on channel morphology (Cross and Moss, 1987), and agricultural runoff (Dodds et al., 2004). Further, numerous Great Plains fishes have been declining for decades because of changing landuse and stream flow patterns (Cross and Moss, 1987; Taylor, 2010; Gido et al., 2010). The objective of this study was to identify local habitat factors associated with the diversity and density of fishes in two protected prairie watersheds. Specifically, we evaluated the relative importance of habitat factors associated with fish communities along a stream size gradient and across multiple seasons and years. Our temporal extent of sampling allowed us to identify the consistency of habitat associations across a variety of biotic and abiotic conditions both spatially and temporally and helped identify the relative importance of local habitat in structuring fish communities within stream networks. Matthews (1988) stated the need for a "frame of reference" for considering how these systems now differ from their pristine state. Many studies focus on systems that are currently under the influence of anthropogenic alteration. Our study focuses on two large portions of protected tallgrass prairie, and results might be used as a baseline for conservation and comparison for small bodied prairie stream fishes.

\section{Methods \\ STUDY AREA}

Fishes were sampled at three locations on Kings Creek $\left(17.5 \mathrm{~km}^{2}\right.$ watershed area above lowermost site), on the Konza Prairie Biological Station (KPBS), and from four locations on Fox Creek $\left(88.4 \mathrm{~km}^{2}\right.$ watershed area above lowermost site) on the Tallgrass Prairie National Preserve (TPNP; Fig. 1). Kings Creek is a tributary in the Kansas River Basin and Fox Creek is located in the Cottonwood/Neosho River Basin. Our lowermost site on Kings Creek was roughly $5.9 \mathrm{rkm}$ from the Kansas River (a $7^{\text {th }}$ order river) and on Fox Creek was roughly $5.2 \mathrm{rkm}$ from the Cottonwood River (a $5^{\text {th }}$ order river). Both areas are owned by The Nature Conservancy and are managed by Kansas State University (KPBS) and the National Park Service (TPNP) with a combination of fire and grazing to maintain native tallgrass prairie. 


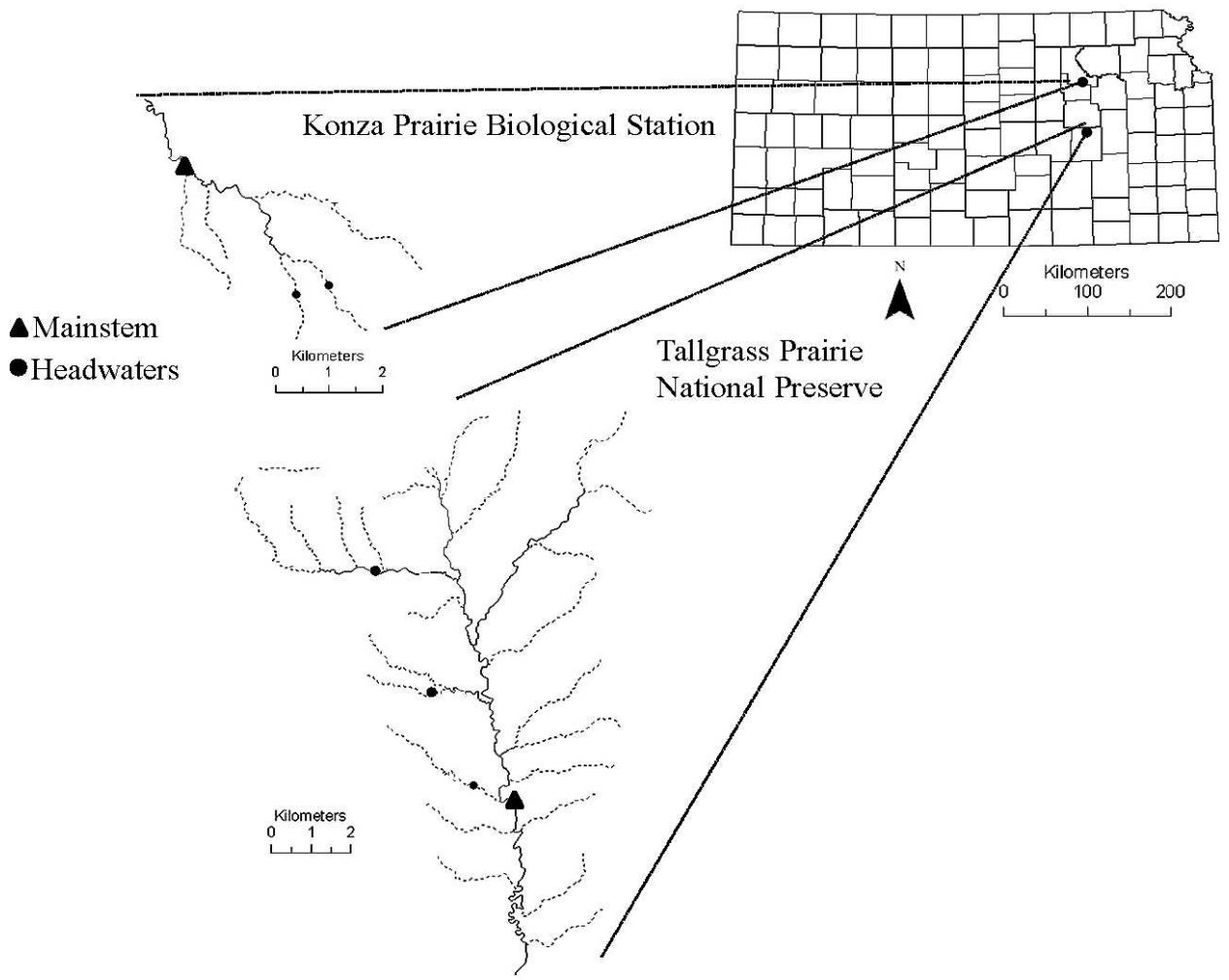

Fig. 1. - Location of study sites (black dots) within Kings Creek and Fox Creek watersheds in eastern Kansas. Triangles indicate mainstem sites and circles indicate tributary sites

Bison are the primary grazers on portions of Kings Creek, whereas Fox Creek watersheds have both bison and cattle. In each watershed, one sample site was established on the mainstem stream and 2-3 sites were located in headwater tributaries (Fig. 1). Although riffles were sampled at mainstem sites when flowing, only pools were consistently sampled among sites (13 per site) and thus were the focus of our analysis. Moreover, because riffles were intermittent, species diversity was typically much lower and a subset of the species captured in pools.

\section{FISH COLLECTION}

Fishes were sampled with single pass backpack electrofishing with two netters in May, Aug. and Nov. from 2006-2011 at Kings Creek and a combination of backpack electrofishing with two netters and a $4.6 \times 1.8 \mathrm{~m}$ seine with $3.2 \mathrm{~mm}$ mesh from 2008-2011 at Fox Creek. Seining occurred at two tributary sites and one main stem site in the Fox Creek watershed that had habitats too deep $(>1 \mathrm{~m})$ to be efficiently sampled with backpack electrofishing. Fishes were identified to species, measured (total length, $\mathrm{mm}$ ) and released into the pool from which they were collected. Pool area was measured and abundance was expressed as density (number of individuals per $\mathrm{m}^{2}$ ).

To account for differences in species size structure, the most abundant species $(>10 \%$ of total individuals captured) were subdivided by size class (juvenile or adult). Size classes were 
TABLE 1.-Length at maturity and references for classification of abundant fish species $(>10 \%$ of total individuals captured) as juvenile or adult

\begin{tabular}{|c|c|c|c|}
\hline \multicolumn{4}{|c|}{ Most abundant species } \\
\hline Common name (scientific name) & Watershed & $\begin{array}{l}\text { Length at } \\
\text { maturity }\end{array}$ & Reference \\
\hline $\begin{array}{l}\text { Central stoneroller (Campostoma } \\
\text { anomalum) }\end{array}$ & Kings/Fox & 65 & $\begin{array}{l}\text { Lennon and Parker 1960, Becker } \\
1983\end{array}$ \\
\hline $\begin{array}{l}\text { Orangethroat darter (Etheostoma } \\
\text { spectabile) }\end{array}$ & Kings/Fox & 45 & Small 1975 \\
\hline Creek chub (Semotilus atromaculatus) & Kings/Fox & 75 & $\begin{array}{l}\text { Lewis and Elder 1953, Gunning and } \\
\text { Lewis } 1956\end{array}$ \\
\hline $\begin{array}{l}\text { Southern redbelly dace (Phoxinus } \\
\text { erythrogaster) }\end{array}$ & Kings & 55 & Stasiak 2007 \\
\hline Green sunfish (Lepomis cyanellus) & Fox & 60 & Carlander 1977, White 1971 \\
\hline Cardinal shiner (Luxilus cardinalis) & Fox & 65 & \\
\hline Redfin shiner (Lythrurus umbratilis) & Fox & 45 & Matthews and Heins 1984 \\
\hline Bluntnose minnow (Pimephales notatus) & Fox & 50 & Becker 1983 \\
\hline
\end{tabular}

based on published literature accounts of size at maturity and notable breaks in size structure were verified by length frequency histograms from our monitoring (Table 1). Total density without size class separation was used for rare species $(<10 \%$ of total individuals captured) to avoid excessive zero values in our data analyses.

\section{HABITAT VARIABLE MEASUREMENTS}

In each pool, discharge, substrate, depth, velocity, width, and percent canopy cover were measured along 3 transects. Total length of each pool was measured and multiplied by mean pool width to calculate pool area. Depth $(\mathrm{m})$, current velocity $(\mathrm{m} / \mathrm{s}$ taken at $60 \%$ depth, using a Marsh-McBirney Model 2000 flowmeter) and substrate size class (based on modified Wentworth scale; Cummins, 1962) were quantified at five points along each transect. Substrate size classes were numerically scored [1 (clay/bedrock), 2 (silt), 3 (sand), 4 (gravel), 5 (pebble), 6 (cobble) and 7 (boulder)] to give an average size for each habitat sampled. Discharge $\left(\mathrm{m}^{3} / \mathrm{s}^{2}\right)$ was calculated by multiplying mean depth $(\mathrm{m})$ and width $(\mathrm{m})$ to get area, and then multiplying area by the average current velocity $(\mathrm{m} / \mathrm{s})$ for each habitat. Percent canopy cover for each pool was estimated by averaging the densiometer readings at the center of each of the three transects per pool. In stream cover throughout the pool was characterized as log complex, aquatic vegetation, undercut bank, log, brush pile, bank grass, or root wads. Area of cover was measured and divided by total pool area to give the percent of the pool containing cover.

\section{DATA ANALYSIS}

Regression analyses and ordination were used to evaluate the relative importance of habitat variables in structuring fish assemblages across multiple temporal scales in each watershed. Separate analyses were conducted for the two watersheds because they occurred in different drainages and had notably different species composition and abundance patterns. Habitat variables were tested for normality using normal probability plots (NPPs) and $\log$ transformed when necessary. To characterize associations among habitat variables and identify major gradients across watersheds we used principal components analysis (PCA). Principal components analysis was chosen after an analysis of bivariate relationships 
between habitat variables revealed linear relationships (Borcard et al., 2011). To avoid multicollinearity among habitat variables, we examined variance inflation factors (VIF) and removed redundant variables (VIF < 10; Borcard et al., 2011) prior to running the PCA. Multiple linear regressions for each watershed were used to evaluate which of the retained habitat variables from the above analysis were the best predictors of species richness. We tested the association between retained habitat variables and fish assemblage structure in each watershed using redundancy analysis (RDA). Permutational ANOVAs (Borcard et al., 2011) evaluated the significance of habitat variables used in the RDAs, and partial RDAs were used to evaluate the relative contribution of habitat variables while factoring out the effects of site, season, and year. Partial RDAs allowed us to evaluate the pure effects of pool habitat characteristics while controlling for spatial and temporal effects on community structure. Analyses were run in program R 2.9.2 using libraries vegan (Oksanen et al., 2009) and car (Fox, 2009).

\section{RESULTS}

\section{HABITAT ASSOCIATIONS}

Habitat gradients and associations among variables summarized by PCA suggested major gradients associated with stream size (e.g., depth, area, discharge and velocity), instream cover, and seasonal changes in canopy cover. Stream width was removed from this analysis because it had a VIF $>10$ and was closely related to area. The two watersheds had similar habitat gradients; smaller streams generally had a greater proportion of instream cover and more canopy cover (Fig. 2). Canopy cover also changed seasonally with the greatest cover in May and August before leaf fall. Pools were deeper in mainstem sites (mean $=0.26 \mathrm{~m}$, $0.83 \mathrm{~m}$ ) than tributaries (mean $=0.11 \mathrm{~m}, 0.48 \mathrm{~m}$ ) in both Kings and Fox creeks, respectively, but there was a high degree of overlap.

\section{FISH COMMUNITY STRUCTURE}

Species richness was generally higher at sites in Fox Creek [mean $=11$, standard deviation $(\mathrm{SD})=3.9$ ] than in Kings Creek (mean $=7$, $\mathrm{SD}=2.2)$. In Fox Creek, Lepomis cyanellus (green sunfish), Campostoma anomalum (central stoneroller), Luxilus cardinalis (cardinal shiner), Lythrurus umbratilis (redfin shiner), Pimephales notatus (bluntnose minnow), Semotilus atromaculatus (creek chub), and Etheostoma spectabile (orangethroat darter) all had $>10 \%$ of the total number of individuals captured. The most abundant species in Kings Creek were C. anomalum, Phoxinus erythrogaster (southern redbelly dace), S. atromaculatus, and E. spectabile. Mainstem sites had higher richness than tributaries within watersheds. In Kings Creek, a mean of 8.0 (range $=4$ to 13) species occurred in the mainstem, whereas mean richness in tributaries was 4 (range $=3$ to 4 ). Mainstem Fox Creek has a mean species richness of 15.0 (range $=8$ to 19$)$ compared to 9.2 (range $=7$ to 13 ) species in tributaries.

\section{FISH COMMUNITY STRUCTURE HABITAT ASSOCIATIONS}

Multiple regression suggested that species richness was positively associated with area (partial $r=0.70)$ and discharge (partial $r=0.50)$ in Fox Creek $\left(\mathrm{df}=15\right.$, Adj. $\mathrm{R}^{2}=0.60, \mathrm{P}<$ 0.001 ; Fig. 3). In Kings Creek species richness was only associated with area $\left(\mathrm{df}=17, \mathrm{R}^{2}=\right.$ 0.44, P $<0.001$; Fig. 3).

Redundancy analysis followed by permutational ANOVA indicated that depth, area, percent canopy cover and substrate size were associated with fish community structure in both watersheds (Fig. 4). Partitioning variation among predictor variable categories 

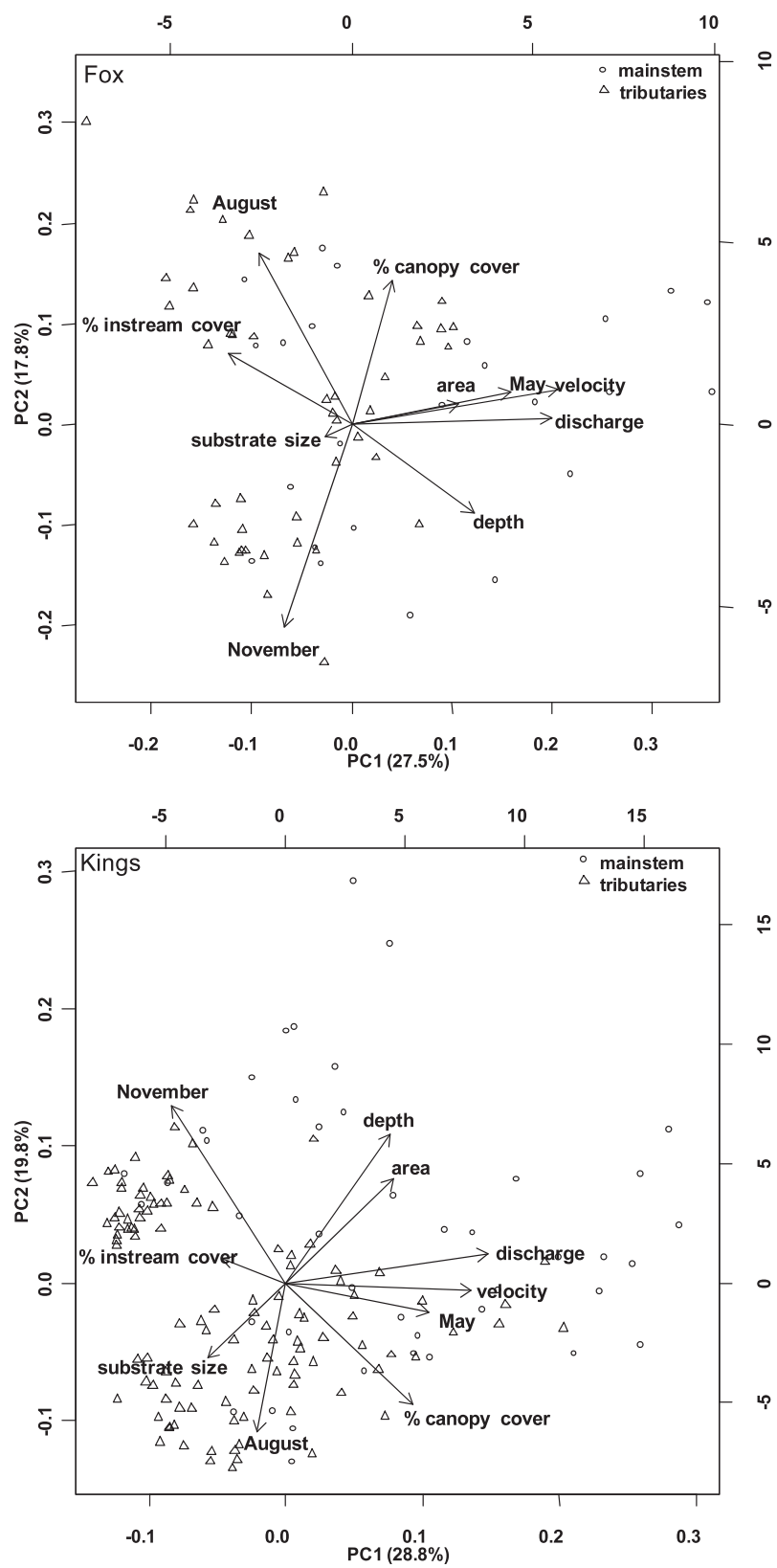

Fig. 2.-Principal components analyses (PCAs) including habitat and seasonal variables in Fox Creek (top) and Kings Creek (bottom). Each dot represents one sample site (e.g., pool 1, Nov. 2011) and symbols represent mainstem (circles) or tributary sample sites (triangles) 


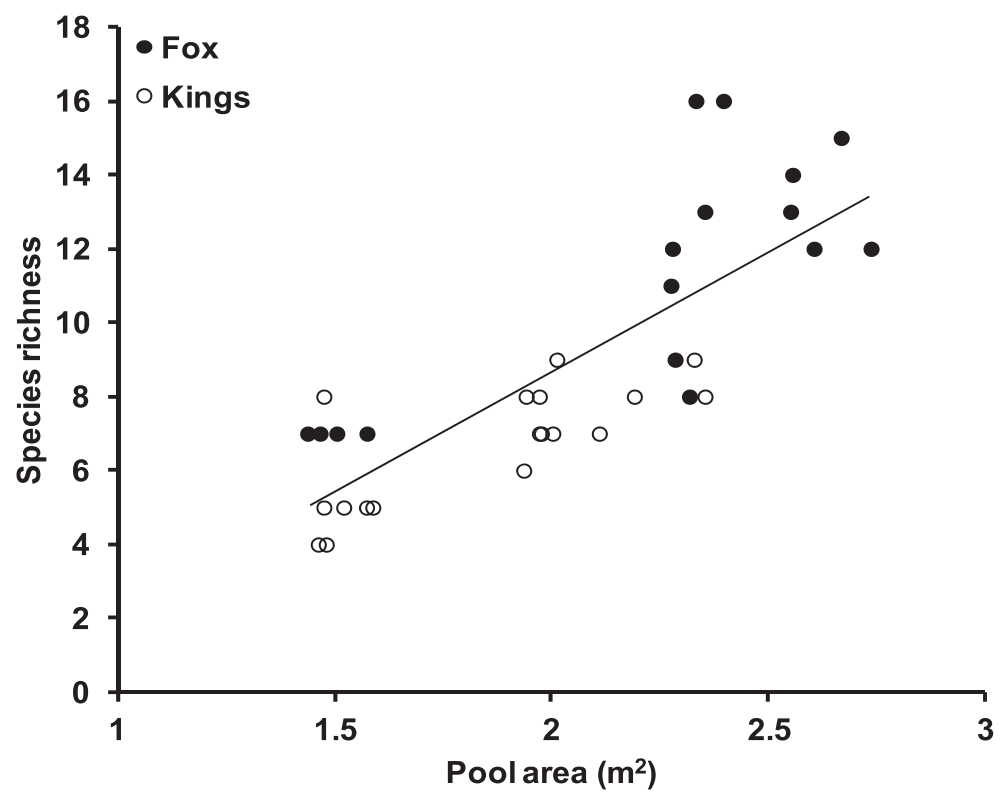

Fig. 3.-Multiple regression of pool area (independent variable) and species richness (dependent variable) for Fox Creek (closed circles; slope $=0.014$, df $=15, \mathrm{r}=0.70, \mathrm{P}<0.001$ ) and Kings Creek (open circles; slope $\left.=0.018, \mathrm{df}=17, \mathrm{R}^{2}=0.44, \mathrm{P}<0.001\right)$. In Fox Creek, species richness was positively associated with area (partial $r=0.70$ ) and discharge (partial $r=0.50$ ), this figure shows only area for both watersheds. An analysis of covariance (ANCOVA) found no significant difference between the slopes for Kings and Fox creeks

(habitat, season, and year) with partial RDAs found that habitat variables explained $14 \%$ (Kings Creek) and 13\% (Fox Creek) of the variance in fish community structure (Table 2). Spatial variability (i.e., Site) explained slightly less $(<12 \%)$ variation than habitat in both watersheds. Although temporal variation in fish community structure was significant in Kings Creek [both year (9\%) and season (6\%) were significant], these variables were not significant in the Fox Creek model.

\section{INDIVIDUAL FISH SPECIES HABITAT ASSOCIATIONS}

Prairie stream fishes exhibited ontogenetic shifts in habitat associations, where adults and juveniles of the same species responded differently to the same habitat variables (Fig. 4). Ontogenetic habitat shifts were more explicit in Kings Creek, where juveniles generally were associated with shallower habitats, as indicated by negative axis 1 and 2 scores in contrast to positive axis 1 or 2 scores for adults. Specifically, juvenile C. anomalum, L. cardinalis and E. spectabile were more abundant in shallow pools in Fox Creek and juvenile P. erythrogaster, C. anomalum and E. spectabile were more abundant in shallow pools in Kings Creek. In both watersheds, juveniles also were positively associated with increasing cover (proportional instream cover in Kings Creek, instream and canopy cover in Fox Creek). Adult fishes (and juvenile S. atromaculatus) were positively associated with depth and area in Kings Creek. In Fox Creek, adults were either positively associated with depth and area, or negatively associated with velocity (i.e., more abundant in slower pools). 

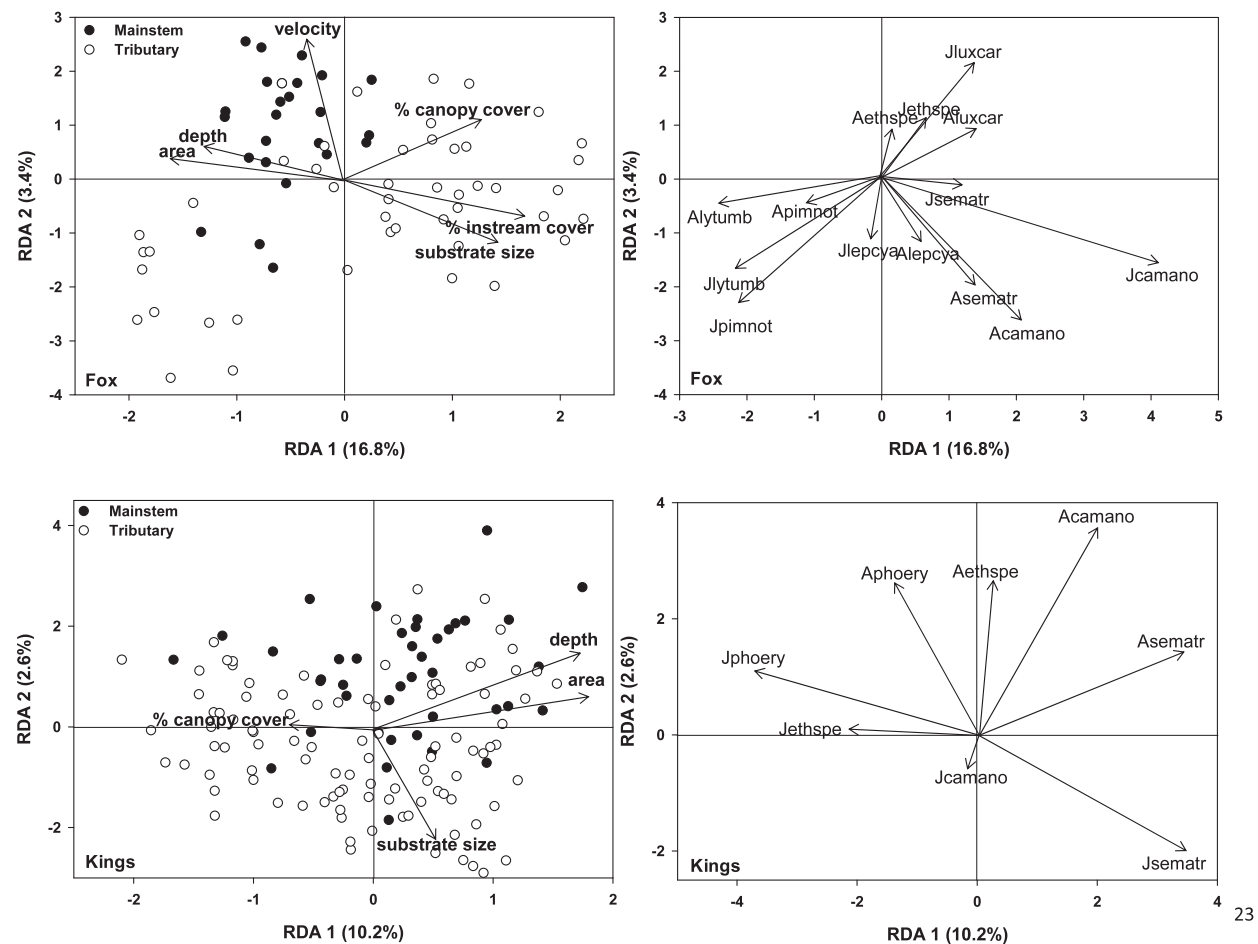

Fig. 4.-Redundancy analyses (RDAs) illustrating species-habitat associations of common species in two watersheds. Analyses included rare species, but were removed from the figure to alleviate crowding, and those species illustrated no associations. Axes 1 and 2 are significant $(\mathrm{P}<0.05)$ for Kings and Fox creek RDAs. Upper (Fox Creek) and lower (Kings Creek) panels represent the habitat vectors and species loadings. Species codes are the first three letters of the genus and species, a 'J' or 'A' refers to the juvenile or adult size class (e.g., juvenile C. anomalum = Jcamano)

\section{DiscusSION}

The objective of this study was to identify local habitat factors associated with fishes in two protected prairie watersheds, with a broader goal of laying a foundation for a "frame of reference" that might be used in considering how altered Great Plains systems now differ from their pristine state (see Matthews, 1988). We found that pool depth and surface area had the strongest relationship with assemblage composition and these variables likely reflect

TABLE 2.-Proportion of variance explained by habitat factors, site, year, and month in RDA models for each watershed. The last column is the total constrained variation in fish assemblage structure explained by the full model

\begin{tabular}{lccccc}
\hline \hline Spatial scale & Habitat & Site & Year & Season & $\begin{array}{c}\text { Total const. } \\
\text { variation }\end{array}$ \\
\hline Kings Creek & 0.14 & 0.12 & 0.09 & 0.06 & 0.78 \\
Fox Creek & 0.13 & 0.11 & NS & NS & 0.88 \\
\hline
\end{tabular}

NS $=$ Not significant 
a gradient of stream size and permanence that is highly correlated with temperature and dissolved oxygen. Falke et al. (2010) found that local scale spawning habitat influenced both occupancy and relative abundance probabilities of plains fish larvae. Specifically, Hybognathus hankinsoni (brassy minnow) required large, deep, backwater habitats for successful spawning. They proposed that while many stream fish species appear to be habitat generalists, during spawning some taxa switch to habitat specialization. A diversity of habitats is likely important to plains stream fishes emphasizing the need to conserve all habitat types in prairie systems. We found juveniles use shallower waters likely as a refuge from piscivorous fishes (Gorman, 1988; Schlosser, 1988, Labbe and Fausch, 2000). Accordingly, positive associations of adult fishes and pool area and depth are explained partly because larger individuals are less effectively consumed by piscivorous fishes ( $S$. atromaculatus and L. cyanellus). Deeper pools are also more likely to remain wet during dry periods and provide more food resources and refuge from terrestrial predators (Power, 1987; Lonzarich and Quinn, 1995). Semotilus atromaculatus is one of the largest of the common species in our samples, and terrestrial predator avoidance might explain why this species seems to prefer deep habitats. This result is concurrent with Grossman and Freeman (1987) who found that $S$. atromaculatus were significantly over represented in deep areas and Edwards (1997) who showed that S. atromaculatus avoids strong flows. The species depth relationships from this study provides empirical support for the conceptual model by Power (1987) that illustrated size specific shifts in depth preference, where small bodied fish use shallow waters to avoid aquatic predators and large bodied individuals used deeper areas to avoid terrestrial predators.

Fishes also showed associations with measures of pool cover. Etheostoma spectabile was positively associated with percent instream cover and percent canopy cover, which is consistent with studies that report associations with vegetation, brush, and rocks that provide protection (Kuehne and Barbour, 1983; Page, 1983). Similarly, our results indicated most juveniles were positively associated with percent instream cover or percent canopy cover (e.g., E. spectabile, P. erythrogaster, C. anomalum, L. cardinalis). This might further illustrate predator avoidance by these small individuals as mortality via predation can be $50 \%$ greater in habitats with less complex structures (Lonzarich and Quinn, 1995).

Seasonal changes explained little variation in assemblage structure suggesting pool assemblages were relatively stable over time. This finding is in contrast to the view that prairie streams are regulated by stochastic (not deterministic) forces but is consistent with the findings of Ross et al. (1985) that found a harsh drought summer had no lasting effect on stability of a prairie stream fish community. They concluded that fish communities in harsh prairie streams may be relatively stable and persistent, despite major changes in environmental quality, and suggest that resistance and adjustment stability are the main reasons driving community persistence. Schlosser (1987) had similar conclusions and suggested harsh headwaters to be dominated by small bodied, short lived "colonizing" species. Likewise, the majority of species present in these prairie streams are adapted to highly variable systems and can be classified as opportunistic life history strategists characterized by young age at maturation, low fecundity, and low juvenile survival (Winemiller and Rose, 1992). Although temporal variation in habitat availability should drive seasonal changes in assemblage structure (e.g., Grossman and Freeman, 1987), pool habitats in prairie streams can be stable if they are spring fed as was the case in our systems. Evidently, a combination of environmental filters and species adaptation is driving the assemblage composition in small prairie streams. Thus, maintenance of these permanent pools and habitat structure within them may be critical refugia for the persistence of species. 
Other factors (i.e., functional groupings, biotic interactions) that were not the focus of this study might explain distributions or lack of habitat association for various fish species. Some common stream fishes in prairies, like L. cyanellus, can be classified as generalist species and might not be influenced by spatial or temporal variation in habitat availability. Further, habitat associations of rare and potentially transient species $(<10 \%$ total number of individuals captured) are difficult to detect because of small sample sizes. However, species that were rare based on abundance measurements were typically consistently sampled at our sites. Also, biotic interactions might be more influential than habitat in some circumstances where one species provides critical habitat for another species (Gorman, 1988). For example, L. umbratilis is a nest associate with L. cyanellus (Hunter and Wisby, 1961) which might make L. cyanellus presence more important that other habitat factors for L. umbratilis distribution. Similarly, S. atromaculatus are typically nest associates with $C$. anomalum (Becker, 1983).

Our data were collected from two streams in the Flint Hills, the only region with remaining tallgrass prairie watersheds, and might inform management and conservation of biodiversity of these systems. For example, ontogenetic shifts in habitat use by prairie stream fishes suggest the maintenance of connectivity among heterogeneous pools might be important for species persistence. This is especially true in Kings Creek where shallow pools (i.e., juvenile refugia) tend to occur in upstream headwaters. In contrast, Fox Creek sites had both deep and shallow areas within a pool or site. Further, natural spring flows that maintain stable pool volumes and habitat complexity in the form of cover are local habitat features that may be critical for the persistence of prairie stream fishes. Unfortunately, many of these spring fed streams are dammed, which has created refuges for lentic adapted species (e.g., L. cyanellus) and altered natural flow regimes (Kerns and Bonneau 2002). Indeed, the Fox Creek watershed has a number of small impoundments and species such as L. cyanellus are more dominant in this system than in Kings Creek which does not have any impoundments.

In conclusion whereas the dominant landcover of North America was historically prairie these ecosystems are one of the most endangered in the region (Samson and Knopf, 1994). Maintenance of critical habitat features within this fragmented landscape is likely necessary to ensure the persistence of biodiversity in this highly endangered ecosystem.

Acknowledgments. - Assistance with fish and habitat surveys was provided by Katie Bertrand, Tyler Pilger, Nathan Franssen, Dustin Shaw, Josh Perkin, David Hoeinghaus, Anna Hoeinghaus, and Darren Thornbrugh. We would like to thank Matt Troia for assistance with GIS map images. Darin McCullough from TNPP provided logistical support. The National Science Foundation Konza Prairie LTER and Kansas State University provided funding. Collecting and research permits were provided by Konza Prairie Biological Station and the Kansas Department of Wildlife, Parks and Tourism.

\section{Literature Cited}

Angermeier, P. L. ANd J. R. KARR. 1984. Relationships between woody debris and fish habitat in a small warm-water stream. T. Am. Fish. Soc., 113:716-726.

Becker, G. C. 1983. Fishes of Wisconsin. The University of Wisconsin Press, Madison. 1052 p.

BOND, N. R. AND P. S. LAKE. 2003. Characterizing fish-habitat associations in streams as the first step in ecological restoration. Austral Ecol., 28:611-621.

Borcard, D., F. Gillet, and P. Legendre. 2011. Numerical ecology in R. Springer, New York.

Carlander, K. D. 1977. Handbook of freshwater fishery biology. The Iowa State University Press, Ames.

Comita, L. S., M. Uriarte, J. Thompson, I. Jonckheere, C. D. Canham, and J. K. Zimmerman. 2009. Abiotic and biotic drivers of seedling survival in a hurricane-impacted tropical forest. J. Ecol., 97:1346-1359. 
Cross, F. B. AND R. E. Moss. 1987. Historic changes in fish communities and aquatic habitats in plains streams of Kansas, p. 155-165. In: W. J. Matthews and D. C. Heins (eds.). Community and evolutionary ecology of North American stream fishes. University of Oklahoma Press, Norman, Oklahoma.

Cummins, K. W. 1962. An evaluation of some techniques for the collection and analysis of benthic samples with special emphasis on lotic waters. Am. Mid. Nat., 67:477-504.

Dodds, W. K., K. B. Gido, M. R. Whiles, K. M. Fritz, and M. J. Matthews. 2004. Life on the edge: the ecology of Great Plains prairie streams. BioScience, 54:207-218.

Edwards, R. J. 1997. Ecological profiles for selected stream-dwelling Texas freshwater fishes. Report to the Texas Water Development Board.

Falke, J. A., K. R. Bestgen, and K. D. Fausch. 2010. Streamflow reductions and habitat drying affect growth, survival, and recruitment of brassy minnow across a Great Plains riverscape. Trans. Am. Fish. Soc., 139:1566-1583.

— K. D. Fausch, K. R. Bestgen, and L. L. Bailey. 2010. Spawning phenology and habitat use in a Great Plains, USA, stream fish assemblage: an occupancy estimation approach. Can. J. Fish. Aquat. Sci., 67:1942-1956.

Fausch, K. D., C. E. Torgersen, C. V. BaXter, And H. W. Li. 2002. Landscapes to riverscapes: bridging the gap between research and conservation of stream fishes. Bioscience, 52:483-498.

Fischer, J. R. AND C. P. Paukert. 2008. Habitat relationships with fish assemblages in minimally disturbed Great Plains regions. Ecol. Freshw. Fish., 17:597-609.

Fox, J. 2009. car: Companion to Applied Regression. R package version 1.2-16.

Franssen, N. R., K. B. Gido, C. S. Guy, J. A. Tripe, S. J. Shrank, T. R. Strakosh, K. N. Bertrand, C. M. Franssen, K. L. Pitts, and C. P. Paukert. 2006. Effects of floods on fish assemblages in an intermittent prairie stream. Freshwater Biol., 51:2072-2086.

Frissell, C. A., W. J. Liss, C. E. Warren, and M. D. Hurley. 1986. A hierarchical framework for stream habitat classification: Viewing streams in a watershed context. Environ. Manage., 10:199-214.

Gelwick, F. P. ANd W. J. Matthews. 1997. Effects of algivorous minnows (Campostoma) on spatial and temporal heterogeneity of stream periphyton. Oecologia, 112:386-392.

Gido, K. B. and D. A. Jackson. 2010. Advances in Stream Fish Community Ecology: Concepts, Approaches and Techniques. American Fisheries Society Symposium Publication Series.

— W. K. DodDS, AND M. E. EBERLE. 2010. Retrospective analysis of fish community change during a half-century of landuse and streamflow changes. J. N. Am. Benthol. Soc., 29:970-987.

Gorman, O. T. AND J. R. KarR. 1978. Habitat structure and stream fish communities. Ecology., 59:507-515. . 1988. The dynamics of habitat use in a guild of Ozark minnows. Ecol. Monogr., 58:1-18.

Grossman, G. D. and M. C. Freeman. 1987. Microhabitat use in a stream fish assemblage. J. Zool., 212:151-176.

—, A. Sostoa, M. C. Freeman, and J. Lobón-Cerviá. 1987. Microhabitat use in a Mediterranean riverine fish assemblage. Oecologia, 73:501-512.

, R. E. RatajCZaK, M. Crahford, and M. C. Freeman. 1998. Assemblage organization in stream fishes: effects of environmental variation and interspecific interactions. Ecol. Monogr., 68:395-420.

Gunning, G. E. And W. M. Lewis. 1956. Age and growth of two important bait species in a cold-water stream in southern Illinois. Am. Mid. Nat., 55:118-120.

Hitt, N. P. And P. L. Angermeier. 2008. Evidence for fish dispersal from spatial analysis of stream network topology. J. N. Am. Benthol. Soc., 27:304-320.

Hunter, J. R. And W. J. Wisby. 1961. Utilization of the nests of green sunfish (Lepomis cyanellus) by the redfin shiner (Notropis umbratilis cyanocephalus). Copeia, 113-115.

JaCkson, J. B. C. AND L. Buss. 1975. Allelopathy and spatial competition among coral reef invertebrates. $P$. Natl. Acad. Sci. U.S.A., 72:5160-5163.

Jackson, D. A., P. R. Peres-Neto, and J. D. Olden. 2001. What controls who is where in freshwater fish communities - the roles of biotic, abiotic, and spatial factors. Can. J. Fish. Aquat. Sci., 58:157-170. 
Kuehne, R. A. and R. W. Barbour. 1983. The American darters. The University Press of Kentucky, Lexington.

LabBe, T. R. and K. D. Fausch. 2000. Dynamics of intermittent stream habitat regulate persistence of a threatened fish at multiple scales. Ecol. Appl., 10:1774-1791.

Layman, C. A. and K. O. Winemiller. 2004. Size-based response of prey to piscivore exclusion in a speciesrich Neotropical river. Ecology, 85:1311-1320.

Leibold, M. A., M. Holyoak, N. Mouguet, P. Amarasekare, J. M. Chase, M. F. Hoopes, R. D. Holt, J. B. Shurin, R. Law, D. Tilman, M. Loreau, and A. Gonzalez. 2004. The metacommunity concept: a framework for multiscale community ecology. Ecol. Lett., 7:601-613.

Lennon, R. E. and P. S. Parker. 1960. The stoneroller, Campostoma anomalum (Rafinesque) in the Great Smoky Mountains National Park. Trans. Am. Fish. Soc., 89:263-270.

Leopold, L. B. ANd J. P. Miller. 1956. Ephemeral streams: hydraulic factors and their relation to the drainagen. Government Printing Office, Washington, U.S.

Lewis, W. M. AND D. Elder. 1953. The fish population of the headwaters of a spotted bass stream in southern Illinois. Trans. Am. Fish. Soc., 82:193-202.

Lobón-CERVIÁ, J. AND P. A. Rincón. 2004. Environmental determinants of recruitment and their influence on the population dynamics of stream-living brown trout Salmo trutta. Oikos, 105:641-646.

LonZarich, D. G. AND T. P. Quinn. 1995. Experimental evidence for the effect of depth and structure on the distribution, growth, and survival of fishes. Can. J. Zool., 73:2223-2230.

Magoulick, D. D. 2000. Spatial and temporal variation in fish assemblages of drying stream pools: the role of abiotic and biotic factors. Aquatic Ecology, 34:29-41.

Marchetti, M. P. and P. B. Moyle. 2001. Effects of flow regime on fish assemblages in a regulated California stream. Ecol. Appl., 11:530-539.

Matthews, W. J. 1988. North American prairie streams as systems for ecological study. J. N. Am. Benthol. Soc., 7:387-409.

Matthews, M. M. and D. C. Heins. 1984. Life history of the redfin shiner, Notropis umbratilis (Pisces:Cyprinidae), in Mississippi. Copeia, 1984:385-390.

Matthews, W. J. and H. W. Robison. 1998. Influence of drainage connectivity, drainage area, and regional species richness on fishes of the Interior Highlands in Arkansas. Am. Mid. Nat., 139:1-19.

Moyle, P. B. And T. Light. 1996. Fish invasions in California: do abiotic factors determine success Ecology, 77:1666-1670.

Oksanen, J., R. Kindt, P. Legendre, B. O’Hara, G. L. Simpson, P. Solymos, M. H. H. Stevens, and H. WAGNER. 2009. vegan: Community Ecology Package. R package version 1.15-4.

PAGE, L. M. 1983. Handbook of darters. TFH Publications, Inc. Ltd., Neptune City, New Jersey.

Perkin, J. S. And K. B. Gido. 2011. Stream fragmentation thresholds for a reproductive guild of Great Plains fishes. Fisheries, 36:371-383.

Poff, N. L., J. D. Allan, M. B. Bain, J. R. Karr, K. L. Prestegaard, B. D. Richter, R. E. Sparks, and J. C. Stromberg. 1997. The natural flow regime. BioScience, 47:769-784.

- AND J. V. WARD. 1989. Implications of streamflow variability and predictability for lotic community structure: a regional analysis of streamflow patterns. Can. J. Fish. Aquat. Sci., 46:1805-1818.

PowER, M. E. 1987. Predator avoidance by grazing fishes in temperate and tropical streams: importance of stream depth and prey size, p. 333-351. In: W. C. Kerfoot and A. Sih (eds.). Predation: direct and indirect impacts on aquatic communities. Hanover: Univ. Press, New England.

1992. Top-down and bottom-up forces in food webs: do plants have primacy? Ecology, 73:733-746.

AND W. J. Matthews. 1983. Algae-grazing minnows (Campostoma anomalum), piscivorous bass (Micropterus spp.), and the distribution of attached algae in a small prairie-margin stream. Oecologia, 60:328-332.

$\longrightarrow,-$, AND A. J. STEWART. 1985. Grazing minnows, piscivorous bass and stream algae: dynamics of a strong interaction. Ecology, 66:1448-1456.

, A. J. Stewart, And W. J. Matthews. 1988. Grazer control of algae in an Ozark mountain stream: Effects of short-term exclusion. Ecology, 69:1894-1898. 
Propst, D. L. ANd K. B. Gido. 2004. Responses of native and nonnative fishes to natural flow regime mimicry in the San Juan River. Trans. Am. Fish. Soc., 133:922-931.

Resh, V. H., A. V. Brown, A. P. Covich, M. E. Gurtz, H. W. Li, G. W. Minshall, S. R. Reice, A. L. Sheldon, J. B. Wallace, and R. C. Wissmar. 1988. The role of disturbance in stream ecology. J. N. Am. Benthol. Soc., 7:433-455.

Romare, P., D. E. Schindler, M. D. Scheuerell, J. M. Scheuerell, A. H. Litt, and J. H. Shepherd. 2005. Variation in spatial and temporal gradients in zooplankton spring development: the effect of climatic factors. Freshwater Biol., 50:1007-1021.

Ross, S. T., W. J. Matthews, And A. A. Echelle. 1985. Persistence of stream fish assemblages: effects of environmental change. Am. Nat., 126:24-40.

Samson, F. and F. Knopf. 1994. Prairie conservation in North America. BioScience, 44:418-421.

SChlosser, I. J. 1985. Flow regime, juvenile abundance, and the assemblage structure of stream fishes. Ecology, 66:1484-1490.

1987. A conceptual framework for fish communities in small warmwater streams, p. 17-24. In: W. J. Matthews and D. C. Heins (eds.). Community and evolutionary ecology of North American stream fishes. University of Oklahoma Press, Norman, Oklahoma.

1988. Predation risk and habitat selection by two size classes of a stream cyprinid: experimental test of a hypothesis. Oikos, 52:36-40.

Small, J. W., JR. 1975. Energy dynamics of benthic fishes in a small Kentucky stream. Ecology, 56:827-840.

STASIAK, R. H. 2007. Southern redbelly dace (Phoxinus erythrogaster): a technical conservation assessment. [Online]. USDA Forest Service, Rocky Mountain Region. Available: http://www.fs.fed.us/r2/ projects/scp/assessments/southernredbellydace.pdf. [12-8-2011].

Statzner, B. 1987. Characteristics of lotic ecosystems and consequences for future research directions, p. 365-390. In: E. D. Schulze and H. Zwolfer (eds.). Ecological Studies 61. Springer-Verlag, Berlin.

TAYLOR, C. M. 2010. Covariation among plains stream fish assemblages, flow regimes, and patterns of water use. In: K. B. Gido and D. A. Jackson (eds.). Advances in stream fish community ecology: concepts, approaches and techniques. American Fisheries Society Symposium Publication Series.

White, G. E. 1971. The Texas golden green: A color mutation of the green sunfish. Prog. Fish-Cult., 33:155.

Winemiller, K. O. and K. A. Rose. 1992. Patterns of life-history diversification in North American fishes: implications for population regulation. Can. J. Fish. Aq. Sci., 49:2196-2218. 